\title{
Molluscan assemblage from a tropical intertidal estuarine sand-mud flat, Gulf of Nicoya, Pacific, Costa Rica (1984-1987)
}

\author{
José A. Vargas-Zamora ${ }^{1,2}$ \& Jeffrey A. Sibaja-Cordero ${ }^{1,2}$ \\ 1. Centro de Investigación en Ciencias del Mar y Limnología (CIMAR), Universidad de Costa Rica, 11501-2060, San \\ José, Costa Rica. javargas@biologia.ucr.ac.cr; jeffro.alejandro@gmail.com \\ 2. Escuela de Biología, Universidad de Costa Rica, 11501-2060, San José, Costa Rica.
}

Received 08-II-2011. C Corrected 20-III-2011. Accepted 05-IV-2011.

\begin{abstract}
The availability of data sets covering more than a year is scarce for tropical environments. Advances in hardware and software speed-up the re-analysis of old data sets and facilitates the identification of hidden data patterns. From February 1984 to April 1987 (49 sampling dates), core samples $\left(17.7 \mathrm{~cm}^{2}, 15 \mathrm{~cm}\right.$ deep) were collected at low tide at a sand-mud flat in the mid upper Gulf of Nicoya estuary, Pacific, Costa Rica. Predator exclusion experiments (cages $0.5 \times 0.5 \times 0.2 \mathrm{~m}$, galvanized wire, mesh size $5 \mathrm{~mm}$ ), were conducted at the site in 1985 (dry and rainy seasons sets). Samples were preserved with 5\% buffered formalin in sea water stained with Rose Bengal, and washed after 24 hours on a 500 micron mesh sieve. The 1120 cores yielded a total of 112 morphological species of which the mollusks were represented by 23 species, and included the bivalves Tellina rubescens, Tagelus bourgeoisae, Dosinia dunkeri and Leukoma asperrima, and the gastropods, Natica unifasciata, Nassarius luteostomus, Costoanachis rugosa and Turbonilla sp. The 23 species are indicative of a relatively rich sedimentary molluscan fauna. $T$. bourgeoisae had a seasonal oscillation, with higher abundances during the rainy seasons. $T$. rubescens was not seasonal, but presented an oscillation with peaks at about 1.5 year intervals. Many empty shells of Cosmioconcha modesta, lower number of $N$. luteostomus and a few of $T$. rubescens were found with boreholes by the predatory snail $N$. unifasciata. T. rubescens was not significantly more abundant inside or outside cages. T. bourgeoisae showed a significant increase within the caged areas. The numerical fluctuations of the mollusks became more important during the rainy season of 1985. Red tide outbreaks in the Gulf of Nicoya in 1985 may have had an impact on the molluscan populations. Rev. Biol. Trop. 59 (3): 1135-1148. Epub 2011 September 01.
\end{abstract}

Key words: Natica, Nassarius, Costoanachis, Turbonilla, Tagelus, Tellina, Dosinia, Leukoma, benthos, estuary, tidal flat, cages, boreholes, Gulf of Nicoya, Costa Rica.

From 1980 to 1983, an ecological survey was conducted in the Gulf of Nicoya estuary to provide baseline information on the Gulf in support of management policies. Many papers covering the fields of physical, chemical and biological oceanography were published (see references in Vargas \& Mata 2004) making this embayment one of the better known tropical estuaries worldwide (Vargas \& Solano 2011). These studies were followed by a three year survey of an intertidal $400 \mathrm{~m}^{2}$ plot in the mid upper estuary (Vargas 1989).
The intertidal survey methods were not specifically designed for the detection of the abundance pattern of any particular species (Vargas \& Solano 2011). However, the gastropods Natica unifasciata, Nassarius luteostomus, Turbonilla sp., and Costoanachis rugosa, and the bivalves, Tellina rubescens, Tagelus bourgeoisae, Leukoma asperrima and Dosinia dunkeri, appeared regularly in the samples over the study period. Information to date on most of these species consists of entries in malacological collections, with scarce data on their abundance 
fluctuations and ecology. The early work by Gonor (1965) on the predator-prey relationships of N. unifasciata on N. luteostomus at Golfito Bay (Pacific, Costa Rica), and the report by Palacios et al. (1986) on the reproduction of the commercially important, Protothaca asperrima (now Leukoma asperrima) from the Gulf of Nicoya, are notable exceptions.

Caging experiments were conducted by Vargas $(1988,1996)$ at the site to test for the impact of crab, fish and bird predation on the benthic community. There were changes in the abundances of several of the numerically dominant species, and in the composition of the community, as revealed by multivariate statistics. However, the relatively lower abundance mollusks were not analyzed further. The advances in hardware and software during the last decades speed-up the re-analysis of old data sets and facilitates the identification of hidden data patterns.

The objective of this paper is to make accesible complementary data on the abundance fluctuations and ecology of this molluscan assemblage (an artificial group of interacting species).

\section{MATERIALS AND METHODS}

From February 1984 to April 1987 (total: 49 sampling dates) core samples $\left(17.7 \mathrm{~cm}^{2}\right.$, $15 \mathrm{~cm}$ deep) were collected by Vargas (1987, 1988) in lower intertidal at the Punta Morales (mean tidal range: $3 \mathrm{~m}$ ) sand-mud flat in the mid upper Gulf of Nicoya $\left(10^{\circ} \mathrm{N}, 85^{\circ} \mathrm{W}\right)$, Pacific coast of Costa Rica. The study was conducted on a $20 \times 20 \mathrm{~m}$ area of the flat, about $20 \mathrm{~m}$ from the edge of a white sand beach (see map in Vargas 1987). In 1984 and 1985, 28 cores $\left(0.05 \mathrm{~m}^{2}\right)$ were collected (12 to 18 days intervals, 25 dates). A monthly sampling scheme was followed $\left(14\right.$ cores, $0.02 \mathrm{~m}^{2}$ ) from 1985 to 1987 (24 dates).

Macropredator (birds, fish and crabs) exclusion experiments (cages $0.5 \times 0.5 \times 0.2 \mathrm{~m}$, galvanized wire, mesh size $5 \mathrm{~mm}$ ), were conducted by Vargas $(1988,1996)$ at the site in 1985 (dry and rainy seasons sets, eigth cages each). He deployed sixteen cages that were pushed $0.1 \mathrm{~m}$ into the sediment and left for periods of one ( 8 cages), two (4 cages) and three (4 cages) months after which they were lifted and 14 cores taken from inside and 14 outside (84 cores each) the caged areas.

Samples were preserved with $5 \%$ buffered Rose Bengal stained formalin in sea water, and washed with freshwater on a 500 micron mesh sieve. Sorted (30X dissecting scope) specimens were stored in $70 \%$ ethanol. A collection of morphological species was assembled and a code asigned to each one. Molluscan species identification was based on Keen (1971), and later updated with Skoglund (1992), Cruz-Soto \& Jiménez-Ramón (1994), Valdés \& Camacho-García (2004), Rodríguez-Sevilla et al. (2009), Magaña \& Espinosa (2009), and www. marinespecies.org (March 2011).

Seasonality and temporal trends for the 49 dates were analyzed with the Generalized Additive Model (GAM) of the free mgcv package in The $R$ Project for Statistical Computing (Wood 2006), with abundance data $\log _{10}(x+1)$ transformed to homogenize variances. The GAM was carried out with the family quasi (Chaloupka et al. 2008). Species abundances inside and outside cages were compared with a paired Student's t test on the log transformed monthly totals (Normality and equality of variances were tested previously). Chi-square tests were used to determine significant season (dry $v s$ rainy) differences. A SIMPER analysis (Clarke \& Warwick 1994, Hammer et al. 2001) was applied to the data for each condition (caged $v s$ uncaged). The percentage of change attributable to mollusks and other assemblages was obtained using PAST (Hammer et al. 2001).

\section{RESULTS}

A total of 1120 sediment cores were processed, representing an area of $1.98 \mathrm{~m}^{2}$. On average, the sediments at the flat were $65 \%$ sand and about 35\% mud. Other information on environmental data is included in Vargas $(1987,1988,1989)$ and Vargas \& Solano (2011).

The 1120 cores yielded a total of 112 species. The polychaete worms were represented 
by 45 species and the crustaceans by 29 . A group of 15 species included flatworms, nemerteans, two sipunculans, oligochaetes, two brachiopods, two echinoderms, hemichordates, a lancelet and a gobiid fish (Vargas 1989).

The mollusks were represented by 23 species and their abundances are included in Table 1. The deposit feeding pink bivalve, Tellina rubescens was most abundant and ranged in length from $5 \mathrm{~mm}$ to $40 \mathrm{~mm}$. Many small bivalves of various shapes and less than $5 \mathrm{~mm}$ were pooled as unidentified juveniles (Table 1). Among the gastropods, Natica unifasciata was observed frequently crawling on the sediment surface and leaving behind a mucous lined track. A group of the scavenger snail, Nassarius luteostomus was observed (Dec. 26th, 1984) feeding on a dead Callinectes arcuatus crab, and a few gaping T. rubescens were found (Aug. 19 ${ }^{\text {th }}, 1985$ ) lying on the sediment surface. The abundances of the bivalves, T. rubescens, T. bourgeoisae, L. asperrima and D. dunkeri, are included in Figs. 1 and 2, for 1984-1985 and 1984-1987, respectively. The abundances of the gastropods, $N$. unifasciata, Turbonilla sp., $N$. luteostomus and C. rugosa collected from 1984 to 1987 are included in Fig. 3. C. rugosa was found only from August 1985 to March 1986 (Fig. 3B). Only the GAModels applied to the abundances of,

TABLE 1

List of mollusks collected by coring at a $400 \mathrm{~m}^{2}$ plot at the Punta Morales intertidal sand-mud flat. Gulf of Nicoya estuary, Pacific coast of Costa Rica (1984-1987). Code numbers as in Vargas (1987, 1988, 1989). G=Gastropoda, B=Bivalvia. General feeding modes for each family: DF (Deposit feeder), SF (Suspension feeder), CA (Carnivores), PA (Parasitic), SC (Scavenger). $\mathrm{N}=$ total number of individuals collected

\begin{tabular}{|c|c|c|c|c|c|}
\hline Code & Class & Family & Species & Feeding modes & $\mathrm{N}$ \\
\hline 50 & B & Tellinidae & Tellina rubescens Hanley, 1844. & DF & 522 \\
\hline 71 & $\mathrm{~B}$ & & Bivalvia, unidentified juveniles. & $\mathrm{FF}$ & 426 \\
\hline 55 & $\mathrm{~B}$ & Solecurtidae & Tagelus bourgeoisae Hertlein, 1951. & $\mathrm{FF}$ & 208 \\
\hline 45 & G & Naticidae & Natica unifasciata Lamarck, 1822. & $\mathrm{CA}$ & 55 \\
\hline 72 & $\mathrm{~B}$ & Pyramidellidae & Turbonilla sp. & PA & 54 \\
\hline 75 & $\mathrm{G}$ & Calyptraeidae & Calyptraea mammilaris (Broderip, 1834). & FF & 49 \\
\hline 46 & G & Nassariidae & Nassarius luteostomus (Broderip \& Sowerby, 1829). & SC & 47 \\
\hline 52 & G & Vitrinellidae & Solariorbis (?) sp. & $\mathrm{DF}$ & 40 \\
\hline 83 & $\mathrm{~B}$ & Veneridae & Leukoma asperrima (Broderip \& Sowerby, 1835). & FF & 38 \\
\hline 49 & B & Veneridae & Dosinia dunkeri (Philippi, 1844). & $\mathrm{FF}$ & 33 \\
\hline 51 & G & Cylichnidae & Acteocina sp. & $\mathrm{CA}$ & 25 \\
\hline 104 & $\mathrm{~B}$ & Carditidae & Carditamera radiata (Sowerby, 1833). & $\mathrm{FF}$ & 22 \\
\hline 99 & G & Columbellidae & Costoanachis rugosa (Sowerby, 1832). & $\mathrm{CA}$ & 21 \\
\hline 54 & B & Tellinidae & Tellidora burneti (Broderip \& Sowerby, 1829). & $\mathrm{DF}$ & 19 \\
\hline 47 & $\mathrm{~B}$ & Columbellidae & Cosmioconcha modesta (Powys, 1835). & $\mathrm{CA}$ & 13 \\
\hline 48 & $\mathrm{~B}$ & Corbulidae & Corbula nasuta Sowerby, 1833. & DF & 9 \\
\hline 53 & G & Nassariidae & Nassarius complanatus (Powys, 1835). & $\mathrm{SC}$ & 9 \\
\hline 100 & G & Cerithiidae & Ceritium stercusmuscarun Valenciennes, 1833. & $\mathrm{SF}$ & 7 \\
\hline 91 & G & Cyrenoididae & Cyrenoida panamensis Pilsbry \& Zetek, 1931. & DF & 6 \\
\hline 101 & $\mathrm{~B}$ & Veneridae & Anomalocardia subrugosa (Wood, 1828). & FF & 5 \\
\hline 119 & $\mathrm{~B}$ & Mactridae & Mactra fonsecana Hertlein \& Strong, 1950. & FF & 3 \\
\hline 70 & $\mathrm{G}$ & Batillariidae & Rhinocoryne humboldti (Valenciennes, 1832). & DF & 1 \\
\hline 90 & G & Nassariidae & Nassarius wilsoni (C.B. Adams, 1852). & $\mathrm{SC}$ & 1 \\
\hline 115 & G & Naticidae & Natica chemnitzii (Pfeiffer, 1848). & $\mathrm{CA}$ & 1 \\
\hline
\end{tabular}



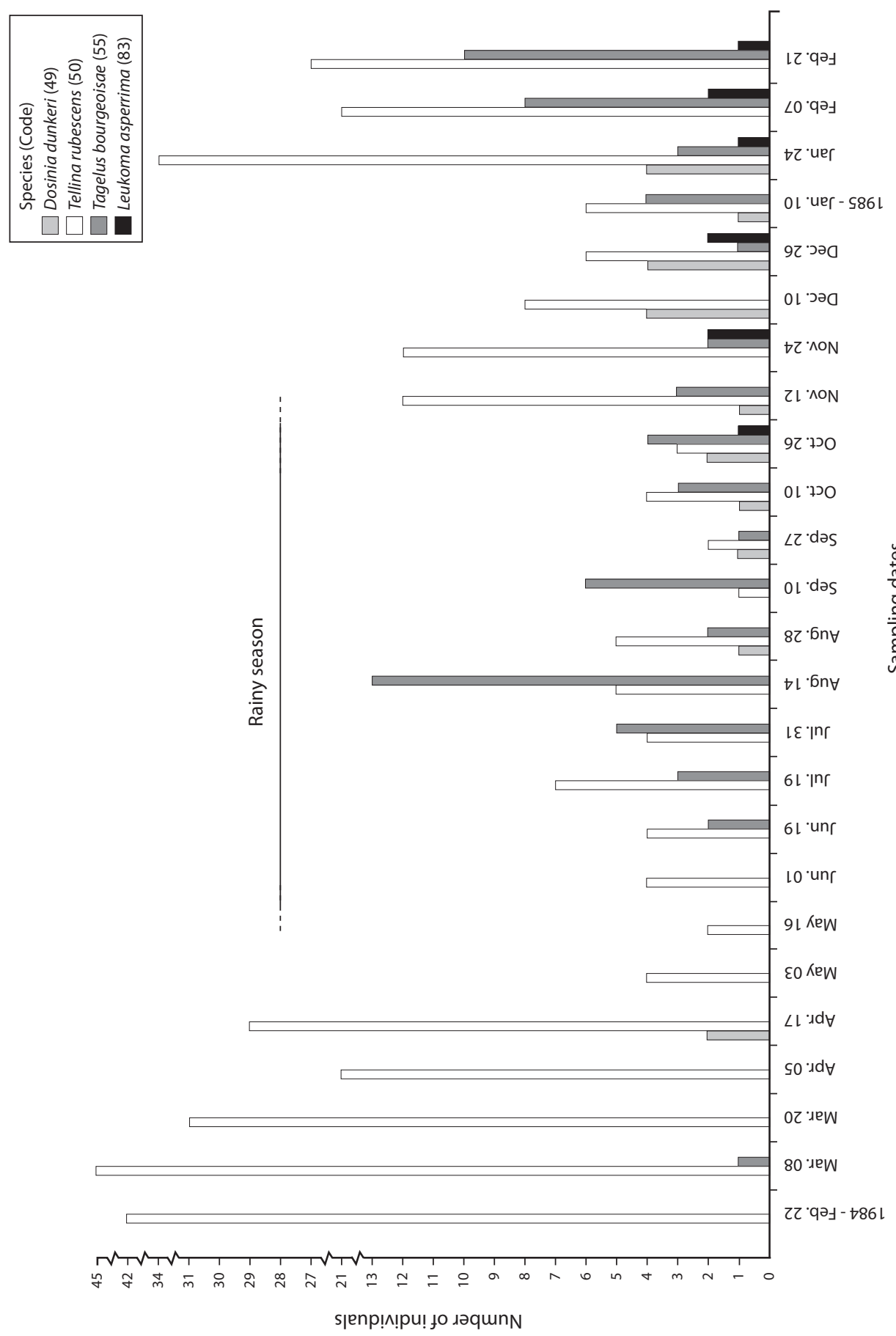

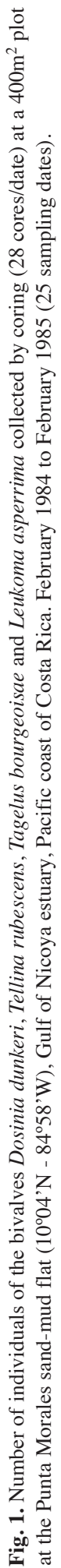




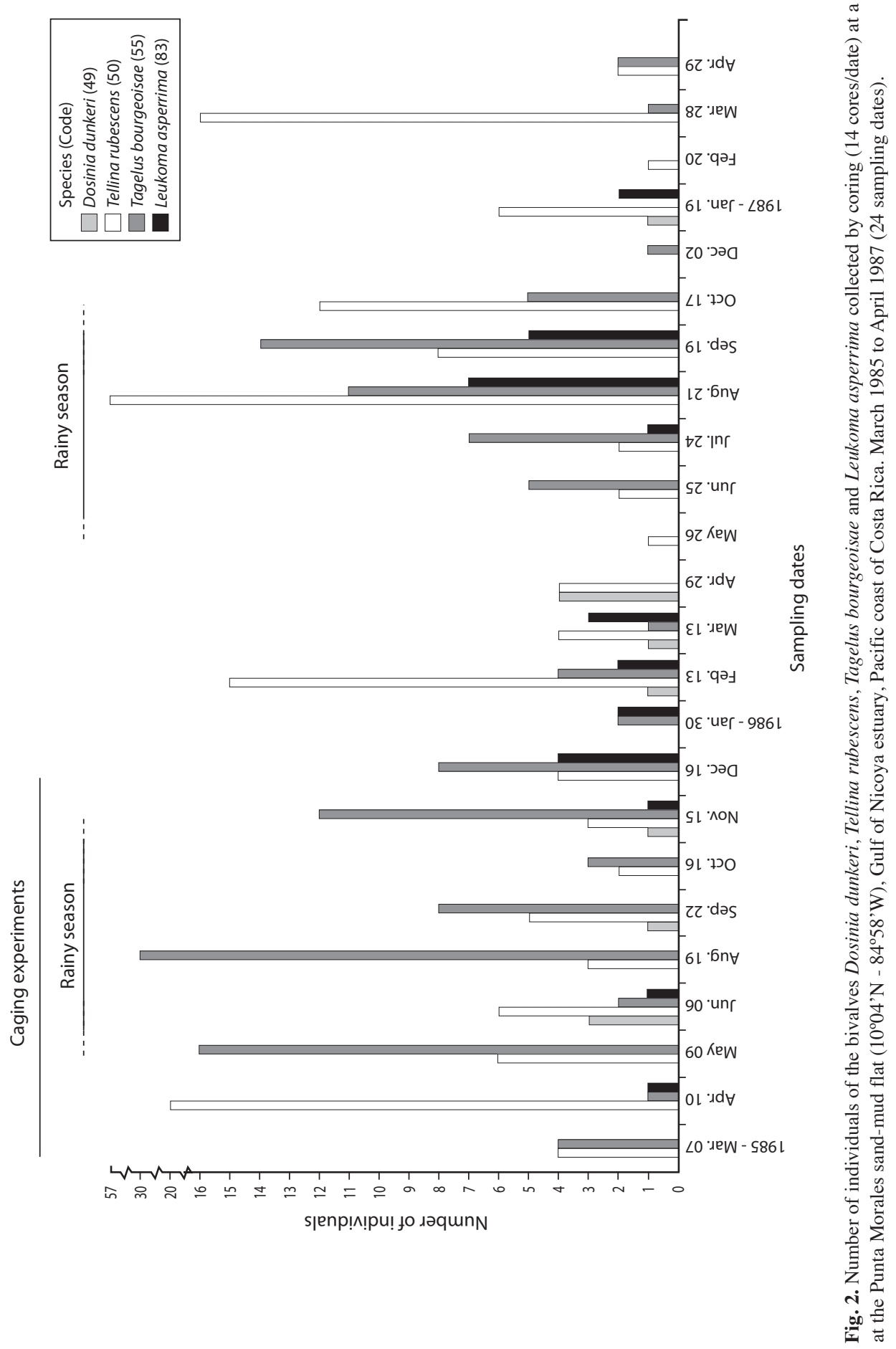




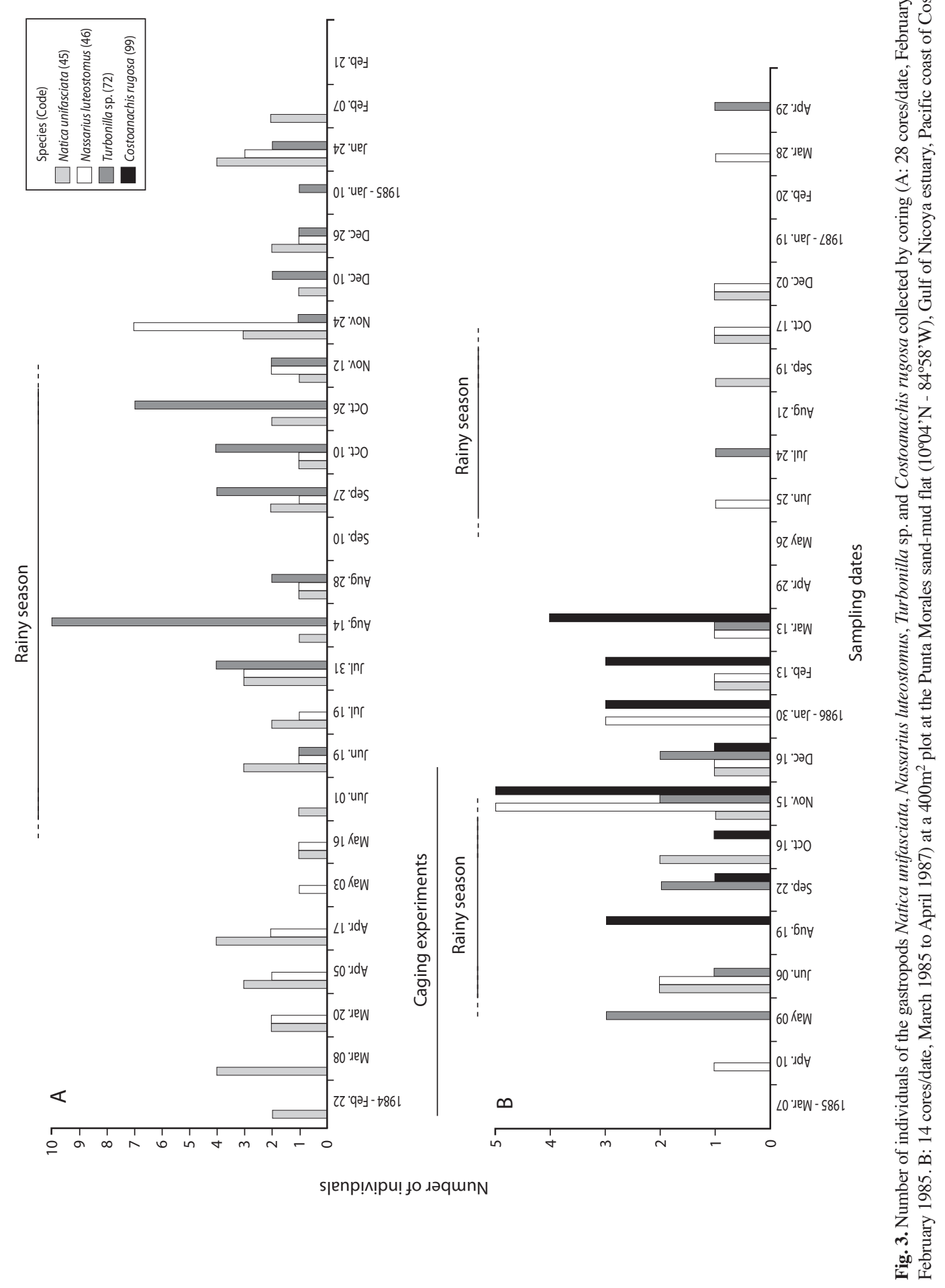


T. bourgeosai, T. rubescens and Turbonilla sp., accounted for greater than $40 \%$ of the explained deviance (Fig. 4). For the 49 dates, a significant seasonal oscillation was detected for T. bourgeoisae $(\mathrm{t}=3.1, \mathrm{p}=0.003)$, with higher abundances during the rainy seasons. Moreover a temporal trend (Fig. 4) was detected with a peak during mid $1985(\mathrm{~F}=6.2, \mathrm{p}=0.002)$. The GAM applied to $T$. rubescens data did not identify a seasonal peak $(\mathrm{t}=-1.63, \mathrm{p}=0.111)$, but rather an oscillation (Fig. 4) with peaks at about 1.5 years intervals $(\mathrm{F}=2.9, \mathrm{p}=0.02)$.

Caging experiments (8 dates) indicated that abundances of $T$. rubescens were not significantly affected by predator exclusion $(\mathrm{t}=0.5$, g.l. $=7, \mathrm{p}=0.642$ ). Both within and outside the cages $T$. rubescens exhibited significant seasonal abundance $\left(\chi^{2}=25.8, \mathrm{p}<0.001\right.$ and $\chi^{2}=9.6$, $\mathrm{p}=0.002$, respectively) with greatest numbers found during the dry season (Fig. 5A,B). On the other hand, T. bourgeoisae showed no significant seasonal differences in abundances inside or outside the cages $\left(\chi^{2}, \mathrm{p}>0.05\right)$, but a significant increase $(\mathrm{t}=2.49$, g.l. $=7, \mathrm{p}=0.042)$ inside the caged areas (Fig. 5C, D).

The relative contribution to changes in molluscan abundances relative to total benthic abundances inside and outside caged areas is included in Table 2. The mollusks were a numerically more important component of the benthos during the rainy season inside (38.2\%) and outside $(56.3 \%)$ the cages than during the dry season (17.7 and $11.2 \%$, respectively). The community presented high values of change during the rainy season than during the dry season for both treatments, inside and outside cages (Table 3). T. bourgeoisae increased its percentage share during the dry season (Table 3), with a peak of $10 \%$ in both treatments in the first months of the rainy season (Table 3 ).
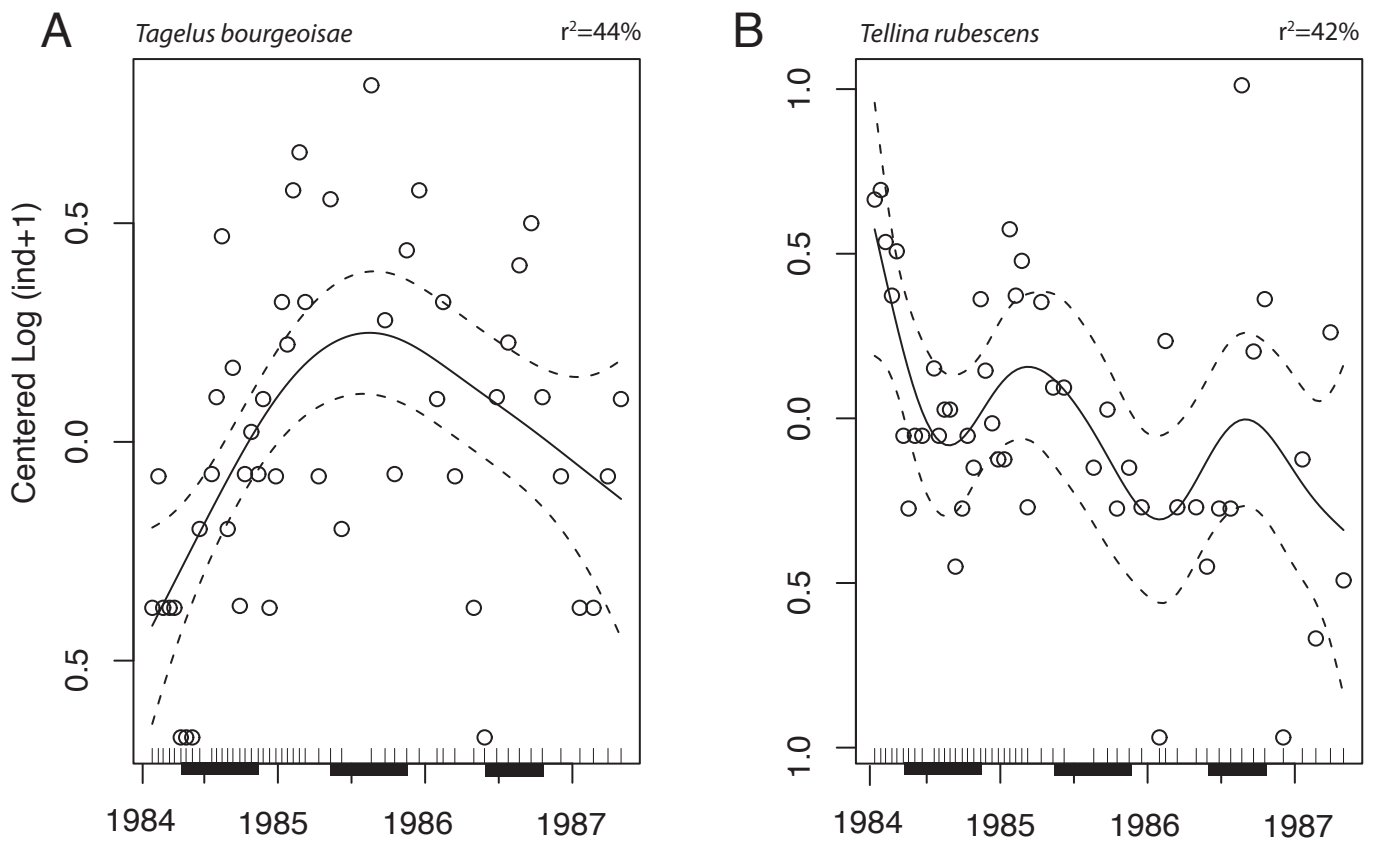

TIME

Fig. 4. Generalized Additive Models (GAM) for the abundances of A: Tagelus bourgeoisae and B: Tellina rubescens, February 1984 to April 1987. Solid line is the fitted value for the model. Broken lines are the $95 \%$ confidence limits. Deviances explained were 44 and $42 \%$, respectively. Dark bars at the bottom $=$ rainy seasons. 

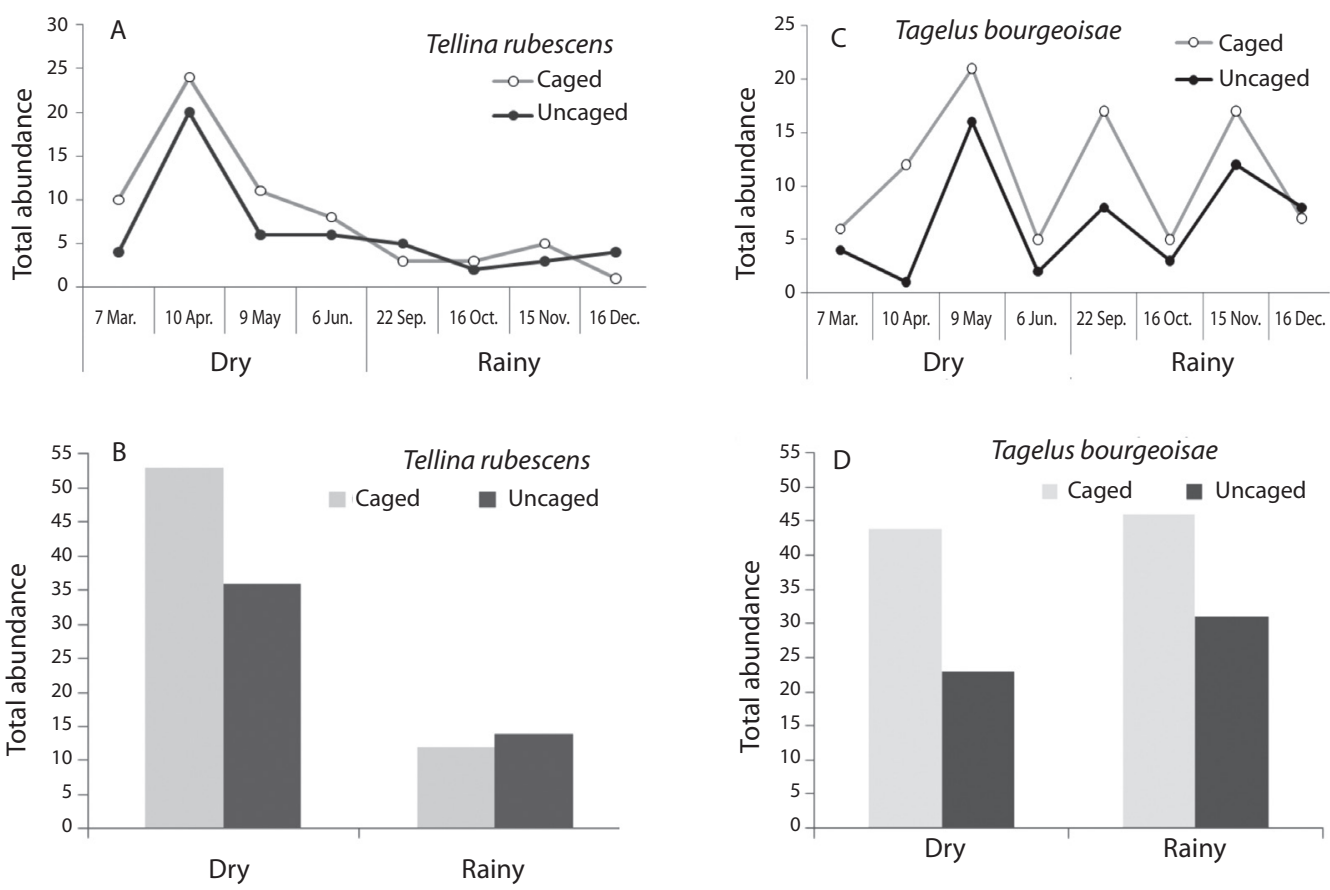

Fig. 5. Total abundances of A: Tellina rubescens, C: Tagelus bourgeoisae in cores taken inside (caged) and outside (uncaged) cages during the dry and rainy season sets of experiments. Cages were sampled after 1 (Mar. 7, Jun. 6), 2 (Apr. 10), and 3 (May. 9) months during the dry season. Cages were also sampled after 1 (Sep. 22, Dec. 16), 2 (Oct. 16) and 3 (Nov. 15) months during the rainy season. B, D: Total abundances inside and outside cages during the dry and rainy seasons. Punta

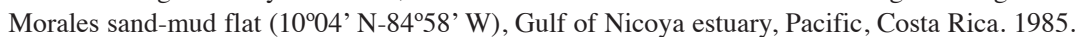

T. rubescens made up a greater percentage of the benthos in the first months of the dry season in both treatments ( $\sim 4$ to $5 \%$ ), Table 3 . The importance of the molluscan assemblage to community change was relatively low compared to the annelids and crustaceans, with a maximum value of $\sim 17 \%$ in both seasons inside or outside cages (Tables 2 and 3).

\section{DISCUSSION}

The 23 molluscan species in this study were collected from an area of $400 \mathrm{~m}^{2}$ and represent only a fraction of the diversity of the Punta Morales sand-mud flat. This intertidal area changes gradually to more sandy conditions to the East and is sharply bounded by a white sand beach to the North and by rocky outcrops to the West (see map in Vargas 1987), and each of these biotopes would be expected to have its own assemblage of species. In a grab survey at 41 stations ( 2 to $46 \mathrm{~m}$ deep, 500 micron sieve) in the Gulf of Nicoya, the benthic macrofauna was represented by 205 species, of which 120 (58.6\%) were polychaete worms, 46 (22.4\%) crustaceans, $22(10.7 \%)$ mollusks and 17 were represented by other groups (Maurer \& Vargas 1984). Therefore the 23 species found at the small site in Punta Morales (Table 3), indicate a relatively rich molluscan fauna. The mollusks of Punta Morales are likely to be even more diverse as additional species of shelled gastropods and unidentified juvenile bivalves were not adequately included in this study. Moreover, Hoisäeter (1998) listed 252 species of shelled gastropods hand collected from 
TABLE 2

Maximun contribution (\%) by the crustacean, annelid, mollusc, and others assemblages to total community (112 spp.) change at the caged and uncaged sampling plots. Punta Morales sand-mud flat $\left(10^{\circ} 04^{\prime} \mathrm{N}-84^{\circ} 58^{\prime} \mathrm{W}\right)$, Gulf of Nicoya estuary, Pacific, Costa Rica. February to December 1985

\begin{tabular}{|c|c|c|c|c|}
\hline Season & Period & Treatment & Assemblage & $\%$ \\
\hline \multirow[t]{8}{*}{ Dry } & Feb-Mar & Caged & Crustacea & 62.7 \\
\hline & May-Jun & & Annelida & 46.7 \\
\hline & May-Jun & & Mollusca & 17.7 \\
\hline & Feb-Apr & & Others & 11.4 \\
\hline & Feb-Mar & Uncaged & Crustacea & 55.9 \\
\hline & May-Jun & & Annelida & 55.7 \\
\hline & Feb-Apr & & Others & 16.3 \\
\hline & Feb-Apr & & Mollusca & 11.2 \\
\hline \multirow[t]{8}{*}{ Rainy } & Aug-Set & Caged & Annelida & 53.0 \\
\hline & Nov-Dec & & Mollusca & 38.2 \\
\hline & Nov-Dec & & Crustacea & 17.4 \\
\hline & Nov-Dec & & Others & 5.6 \\
\hline & Aug-Oct & Uncaged & Annelida & 62.7 \\
\hline & Nov-Dec & & Mollusca & 56.3 \\
\hline & Nov-Dec & & Crustacea & 17.4 \\
\hline & Nov-Dec & & Others & 4.9 \\
\hline
\end{tabular}

TABLE 3

Total percent community (112 spp.) change at the caged and uncaged sampling plots, and percentages $(*=0.0)$ of community change due to the abundances of eight molluscan species (ID codes as in Table 1). Total \% contribution by the eight species is listed in the last column. Dry season (February-June, 1985), rainy season

(August-December, 1985). Punta Morales sand-mud flat (1004' N-84'58' W). Gulf of Nicoya, Costa Rica

\begin{tabular}{|c|c|c|c|c|c|c|c|c|c|c|c|}
\hline \multirow{2}{*}{$\begin{array}{l}\text { Cages on site } \\
\text { (months) }\end{array}$} & \multicolumn{2}{|c|}{$\%$ community change } & \multicolumn{8}{|c|}{$\%$ of community change accounted by each species } & \multirow{2}{*}{ Total } \\
\hline & caged & uncaged & 45 & 46 & 47 & 49 & 50 & 55 & 83 & 99 & \\
\hline \multirow[t]{2}{*}{1 (Feb-Mar) } & 48 & & 0.3 & $*$ & $*$ & $*$ & 0.8 & 0.3 & 0.3 & $*$ & 1.7 \\
\hline & & 29 & 0.3 & $*$ & $*$ & $*$ & 1.0 & 0.3 & 0.3 & * & 1.9 \\
\hline \multirow[t]{2}{*}{2 (Feb-Apr) } & 39 & & 0.3 & 0.3 & $*$ & $*$ & 4.2 & 1.7 & 0.2 & $*$ & 6.7 \\
\hline & & 27 & 0.4 & 0.4 & $*$ & $*$ & 5.0 & 1.6 & $*$ & $*$ & 7.4 \\
\hline \multirow[t]{2}{*}{3 (Feb-May) } & 39 & & $*$ & $*$ & $*$ & 0.5 & 1.0 & 4.1 & 0.3 & $*$ & 5.9 \\
\hline & & 60 & 0.2 & $*$ & 0.2 & $*$ & 0.2 & 2.5 & 0.2 & $*$ & 3.4 \\
\hline \multirow[t]{2}{*}{1 (May-Jun) } & 31 & & $*$ & $*$ & 0.6 & 1.8 & 1.2 & 6.5 & $*$ & $*$ & 10.1 \\
\hline & & 39 & 1.2 & 1.1 & 0.6 & 1.7 & $*$ & 8.0 & 0.6 & $*$ & 13.2 \\
\hline \multirow[t]{2}{*}{1 (Aug-Sep) } & 53 & & $*$ & $*$ & $*$ & $*$ & $*$ & 5.4 & 0.4 & 2.1 & 7.8 \\
\hline & & 54 & $*$ & $*$ & $*$ & 0.5 & 0.9 & 10.0 & $*$ & 0.9 & 12.3 \\
\hline \multirow[t]{2}{*}{2 (Aug-Oct) } & 55 & & 0.4 & $*$ & $*$ & $*$ & $*$ & 10.0 & 0.4 & 0.4 & 11.2 \\
\hline & & 59 & 0.6 & $*$ & $*$ & $*$ & 0.3 & 8.0 & $*$ & 0.6 & 9.5 \\
\hline \multirow[t]{2}{*}{3 (Aug-Nov) } & 70 & & 0.2 & 0.1 & $*$ & $*$ & 0.3 & 2.0 & $*$ & 0.5 & 3.1 \\
\hline & & 58 & 0.3 & 1.3 & $*$ & 0.3 & $*$ & 4.7 & 0.3 & 0.5 & 7.3 \\
\hline \multirow[t]{2}{*}{1 (Nov-Dec) } & 30 & & 0.5 & 2.4 & 0.5 & 0.5 & 0.9 & 2.4 & 1.4 & 1.4 & 9.9 \\
\hline & & 35 & $*$ & 1.6 & $*$ & 0.4 & 0.4 & 1.6 & 1.2 & 1.6 & 6.9 \\
\hline
\end{tabular}


intertidal to 8m depth in Golfo Dulce (Pacific, Costa Rica), with 14 species in the Vitrinellidae and 13 in the Pyramidellidae, and the genus Turbonilla alone represented by 13 species.

Sampling during three years allowed the identification by Vargas $(1987,1988)$ of seasonal oscillations of the community, with samples from the rainy seasons being more similar to each other than those from the dry seasons. The Gulf of Nicoya estuary is seasonal in rainfall (May to November), which in turn influences salinity fluctuations (Voorhis et al. 1983). At the population level, Vargas $(1987,1988)$ also identified groups of species characterized by peaks of abundance coinciding either with the dry or the rainy seasons. For L. asperrima, Palacios et al. (1986) point out that a strong decrease in salinity in the Gulf of Nicoya late in the rainy season (October-November), coincided with the spawning peak of this species. The mangrove cockle, Anadara tuberculosa has its period of greatest spawning activity from May to September (early to mid rainy season) at Punta Morales (Cruz 1984). As a contrast, the razor clam, Tagelus peruvianus has a reproductive peak during January and February (mid dry season) at the intertidal sand flats of Puntarenas, East of Punta Morales (Rojas et al. 1988).

Other species showed variations in abundances which could not be directly related to seasonal cycles. Two species of echinoderms found at the flat were also patchy in their temporal distribution (Vargas \& Solano 2011). The application of GAModels allowed the identification of three abundance trends: peaks during the rainy seasons and a maximum centered at mid 1985 (T. bourgeoisae, Figs., 1, 2, 4A), and an oscillation with periods longer than the annual cycle (T. rubescens, Fig. 4B). Thus, the molluscan fauna at the flat is composed of seasonal and non-seasonal species, whose appearance in the samples might be related to the vagaries of recruitment, immigration and emigration, small scale sediment patchiness, predation impacts, or some combination of these factors. McIntyre (1970), in a study of Tellina tenuis from different intertidal habitats in England, found that variable recruitment from year to year was influenced by biotic and abiotic factors affecting the spawning, planktonic, settlement, and post-settlement phases of this bivalve.

The list (Table 1) of molluscan species revealed different feeding modes, as well as biogenic processess (sediment reworking, mucous-lined tracks, fecal pellet and empty shell productions). Comparisons of tidal flat faunas based on species occupying similar niches, or on unrelated species playing analogous ecological roles, are useful to understand the functioning (energy flow), and structuring (species diversity and abundance), of these ecosystems (Reise 1991). Vargas (1996) pointed out that the mollusks, $N$. unifasciata, $N$. luteostomus, $T$. bourgeoisae and T. rubescens from the Gulf of Nicoya $\left(10^{\circ} \mathrm{N}\right.$, Costa Rica) may play similar ecological roles as the temperate $\left(31^{\circ} \mathrm{N}, \mathrm{USA}\right)$ species, Polinices duplicatus, Nassarius obsoletus, Solen viridis and Tellina texana, respectively. Roles in common include: predation, scavenging, filter and deposit feeding, sediment reworking and formation of feeding tracks. These roles indicate that energy is being transferred by the molluscan assemblage along similar pathways at both latitudes. Moreover, Dittman \& Vargas (2001) compared the faunas of tidal flats in the estuaries of Haughton $\left(19^{\circ} \mathrm{S}\right.$, Australia) and the Gulf of Nicoya. Although there were no molluscan species in common, they found species of the genera Natica and Nassarius at both flats.

$N$. unifasciata has been reported by Gonor (1965) to prey mainly on $N$. luteostomus at the intertidal flats of Golfito bay, an small embayment on the Northern shore of the Golfo Dulce deep anoxic basin (Pacific coast of Costa Rica). N. unifasciata was observed at low tide carrying either a clam or a Nassarius and crawling on the surface for about a meter, then slowly burrowing into the sediment to drill the shell and consume the prey. Hughes (1985) reports that $N$. unifasciata does not forage when covered by the tide in the Pacific coast of Panama, and takes about 50 hours to consume a small Nerita funiculata snail, with most of this time spent drilling through the shell of the prey. 
At the Punta Morales site larger specimens of $N$. unifasciata were observed crawling on the sediment surface but most of the specimens captured by the corer were below the sediment surface. The cores also yielded many empty shells of $C$. modesta, lower number of $N$. luteostomus and a few of T. rubescens bearing boreholes (Fig. 6). Naticacean boreholes are characterized by smooth walls, beveled outer edges, decreasing diameter with depth, circular, and being perpendicular to the prey shell surface (Carriker 1981). Hughes (1985) has pointed out that dietary conditioning and relative abundance of prey items may account for local preferences of $N$. unifasciata over certain prey species. This may be the case with $N$. luteostomus in Golfito bay, and with C. modesta at the Punta Morales flat. However, drilled shells of T. rubescens were scarce at Punta Morales in spite of the relative higher abundance of this clam (Figs. 1, 2). No bored shells of T. bourgeoisae were found during the survey.

At low tide the tidal flats of the Gulf of Nicoya are feeding grounds for resident and migratory shore birds. At the sand-mud flat of Punta Morales 13 species of birds were observed foraging at low tide (Vargas 1988). On a nearby sand flat Pereira (1990) recorded 27 species of birds with Numenius phaeopus, Limnodromus griseus and Catoptrophorus semipalmatus being most numerous throughout the year. These species capture and ingest mainly crustaceans, but also other prey items including bivalves, gastropods, brittle stars, gobiid fish, and worms. To test for the impact of bird foraging on the benthos Pereira (1990) fenced $25 \mathrm{~m}^{2}$ plots with five nylon ropes to a height of $25 \mathrm{~cm}$. This design restricted the access of birds, and the number of invertebrates inside plots was found to be significantly higher that outside.

The use of cages in experiments to test the impact of predators on the benthos in temperate latitudes has produced, with few exceptions significant increases on the number of individuals and species inside the caged areas. For instance, in Northern Germany the bivalve Cerastoderma edule reached densities of 513 individuals under a $400 \mathrm{~cm}^{2}$ area protected by a $1 \mathrm{~mm}$ mesh cage, while only three clams were found in a $400 \mathrm{~cm}^{2}$ of ambient mud (Reise 1985). The response of tropical benthos to caging appears to be dependent on a more complex set of factors and interactions (Vargas 1988, 1996). Cages also affect the hydrodynamic environment inside the caged area; therefore, the observed changes are difficult to relate only to the exclusion of macro-predators (Hall et al. 1990). At high tide the flats around Punta Morales host an assemblage on more than 60 species of fish (Phillips 1983), some of which may feed on the benthos. Vargas $(1988,1996)$ concluded that the relative importance of birds, fish and crabs as predators regulating community structure was not a key factor as evidenced by the results of the caging experiments. However, among the mollusks only $T$. bourgeoisae showed an increase in the number of individuals inside cages (Fig. 5).

The relative importance of the molluscan assemblage in the percent numerical change inside and outside caged areas, increased at the end of the rainy season of 1985 with maximum values of 38.2 and 56.3, respectively (Table 2).

Red tide events were observed in the Gulf of Nicoya between April and November of 1985, with dense patches found in July within a small estuary a few hundred meters from the Punta Morales flat. These outbreaks were caused by several species of toxic and non toxic dinoflagellates and diatoms associated mainly to blooms of Cochlodinium catenatun, but with an outbreak of Gymnodinium catenatum located near the study site in November (Víquez \& Hargraves 1995). Fish mortality (corbinas, croakers and drums) was reported from near Punta Morales during SeptemberOctober of 1985 (Szelistowski \& Garita 1989). Moreover, toxic red tides are known to have had a negative impact on the benthos of Wellington Harbour ( $41^{\circ} \mathrm{S}$, New Zealand) where the polychaetes were affected most, but with important changes in species composition and numerical abundance in the mollusks, crustaceans and echinoderms (Wear \& Gardner 2001). The fact that a few gaping T.rubescens were found on August 19 ${ }^{\text {th }}, 1985$ lying on the 


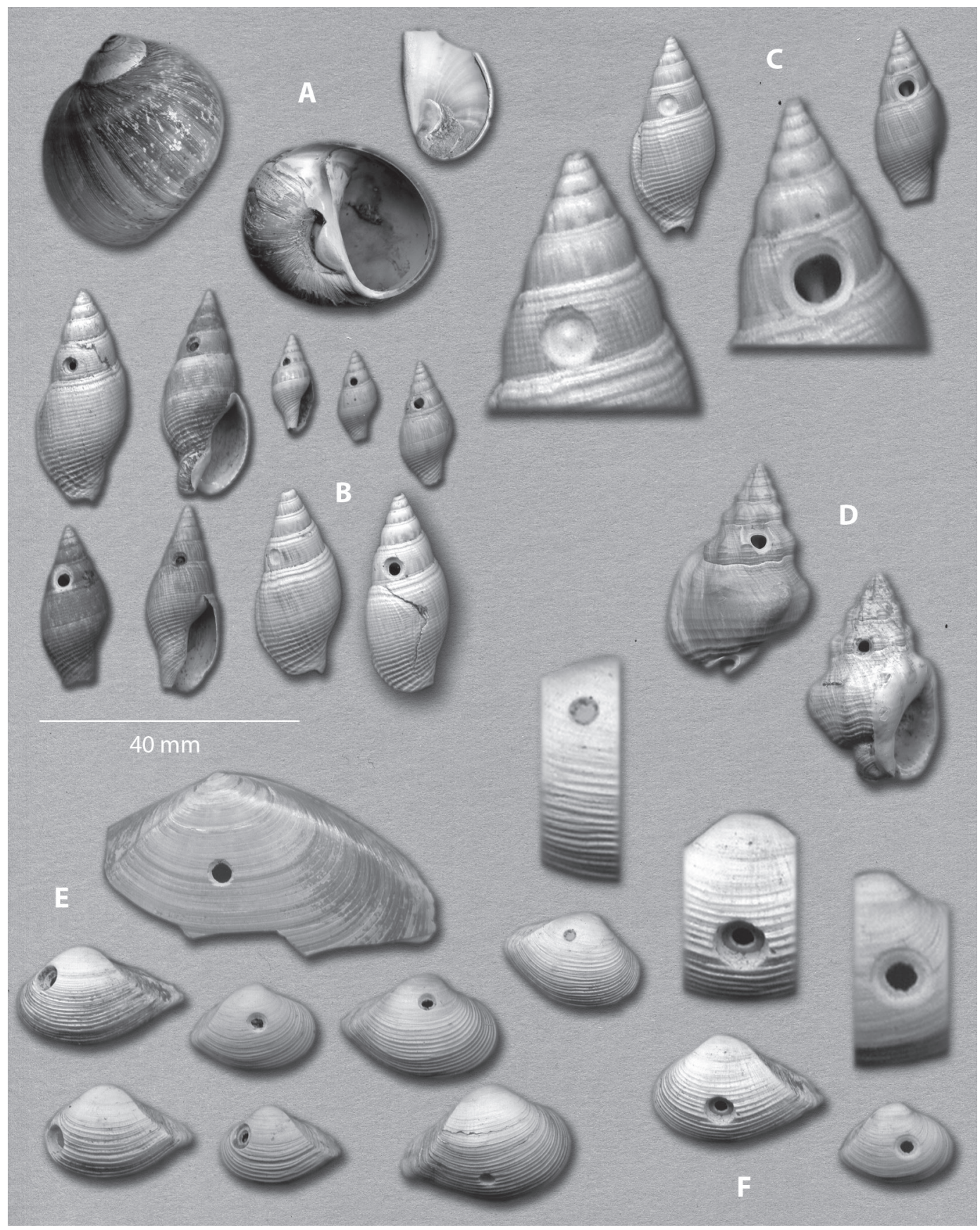

Fig. 6. A. Shell and operculum of Natica unifasciata. B. Shells of Cosmioconcha sp., with boreholes. Note that the position of the borehole appears constant. C. Details of incomplete and complete boreholes. Note the center boss characteristic of incomplete naticacean boreholes. The complete borehole allows the view of the columella, site of attachment for the foot retractor muscle. D. Two shells of Nassarius luteostomus with boreholes. E. Shells of Tellina sp., (top left) and Corbula sp.,

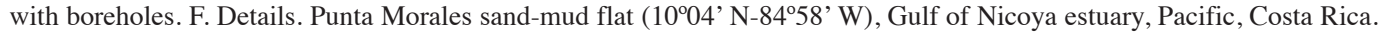


sediment surface at Punta Morales is relevant in this context. Based on the available data, the possibility could no be ruled out that red tides in the Punta Morales region during 1985 also had impacted the molluscan populations.

\section{ACKNOWLEDGMENTS}

We thank Harlan K. Dean and Yolanda Camacho for reviews of the first draft of this paper. Sergio Aguilar prepared the illustrations. Michel Montoya confirmed the identification of the mollusks in 1985 when the senior autor was conducting research for his Ph.D. dissertation at the University of Rhode Island (U.S.A).

\section{RESUMEN}

La disponibilidad de datos con una cobertura mayor al año es rara para ambientes tropicales. Avances en computación y programas de cómputo facilitan el re-análisis de antiguos datos y la identificación de patrones ocultos en ellos. Desde febrero de 1984 hasta abril de 1987 (49 fechas de colecta), muestras de barreno $\left(17.7 \mathrm{~cm}^{2}, 15 \mathrm{~cm}\right.$ de profundidad) fueron recolectadas durante la marea baja en una planicie arenosa-fangosa en la región media del estuario del Golfo de Nicoya, Costa Rica. Experimentos de exclusión de depredadores (jaulas $0.5 \times 0.5 \times 0.2 \mathrm{~m}$, malla galvanizada, poro de $5 \mathrm{~mm}$ ), fueron realizados en el sitio en 1985 (estación seca $v s$ estación lluviosa). Las muestras fueron preservadas con formalina al $5 \%$ en agua de mar teñida con Rosa de Bengala y lavadas después de 24 horas en un tamiz de 500 micras de poro de malla. Los 1120 barrenos produjeron un total de 112 especie morfológicas, de las cuales los moluscos estuvieron representados por 23 especies que incluyen los bivalvos: Tellina rubescens, Tagelus bourgeoisae, Dosinia dunkeri y Leukoma asperrima, y los gastrópodos, Natica unifasciata, Nassarius luteostomus, Costoanachis rugosa y Turbonilla sp. Las 23 especies son indicadoras de una fauna de moluscos relativamente rica. T. bourgeoisae presentó una oscilación estacional, con mayor abundancia durante la estación de lluvias. T. rubescens no fue estacional, pero presentó una oscilación con máximos a intervalos de cerca de 1.5 años. Muchas conchas vacías de Cosmioconcha modesta, un poco menos de $N$. luteostomus y unas pocas de T. rubescens fueron encontradas con perforaciones hechas por el depredador $N$. unifasciata. T. rubescens no fue significativamente más abundande dentro o fuera de las jaulas. $T$. bourgeoisae mostró una falta de abundancia estacional, pero una densidad significativamente mayor dentro de las jaulas. Las fluctuaciones poblacionales de los moluscos fueron más importantes durante la estación de lluvias cuando se les compara con las fluctuaciones de los poliquetos, crustáceos y otros grupos. Mareas rojas en el Golfo de Nicoya durante 1985 podrían haber tenido un impacto en la dinámica de las poblaciones de moluscos.

Palabras clave: Natica, Nassarius, Costoanachis, Turbonilla, Tagelus, Tellina, Dosinia, Leukoma, bentos, estuario, planicies de marea, jaulas, perforaciones, Golfo de Nicoya, Costa Rica.

\section{REFERENCES}

Carriker, M.R. 1981. Shell penetration and feeding by naticacean and muricacean predatory gastropods: a synthesis. Malacologia 20: 403-422.

Chaloupka, M., N. Kamezaki \& C. Limpus. 2008. Is climate change affecting the population dynamics of the endangered Pacific Loggerhead sea turtle?. J. exp. Mar. Biol. Ecol. 356: 136-143.

Clarke, K.R. \& R.M. Warwick. 1994. Change in marine communities: An approach to statistical analysis and interpretation. Bourne, Bournemouth, England.

Cruz, R.A. 1984. Algunos aspectos de la reproducción en Anadara tuberculosa (Pelecypoda: Arcidae) de Punta Morales, Puntarenas, Costa Rica. Rev. Biol. Trop. 32: $45-50$.

Cruz-Soto, R.A. \& J.A. Jiménez-Ramón. 1994. Moluscos asociados a las áreas de manglar de la costa Pacífica de América Central. Guía. Editorial Fundación UNA, Heredia. Costa Rica.

Dittman, S. \& J.A. Vargas. 2001. Tropical tidal flat benthos compared between Australia and Central America, p. 275-293. In K. Reise (ed.). Ecological comparisons of sedimentary shores. Ecological Studies Vol. 151. Springer, Berlin, Germany.

Gonor, J.J. 1965. Predator-prey reactions between two marine prosobranch gastropods. The Veliger 7: 228-232.

Hall, S.J., D. Raffaelli \& W.R. Turrel. 1990. Predatorcaging experiments in marine systems: a reexamination of their value. Amer. Nat. 136: 657-672.

Hammer, O., D.A.T. Harper \& P.D. Ryan. 2001. PAST: Paleontological statistics software package for education and data analysis. Paleontol. Electr. 4: 1-9.

Hoisäeter, T. 1998. Preliminary check-list of the marine, shelled gastropods (Mollusca) of Golfo Dulce, on the Pacific coast of Costa Rica. Rev. Biol. Trop. 46 (Suppl. 6): 263-270.

Hughes, R.N. 1985. Predatory behaviour of Natica unifasciata feeding intertidally on gastropods. J. Moll. Stud. 51: 331-335. 
Keen, A.M. 1971. Sea shells of tropical West America: marine mollusks from Baja California to Peru. Stanford University, Stanford, USA.

Magaña, J.A. \& J. Espinosa. 2009. Bivalves, p. 387-398. In I.S. Wehrtmann \& J. Cortés (eds.). Marine Biodiversity of Costa Rica, Central America. Monographiae Biologicae 86. Springer, Dordrecht, The Netherlands.

Maurer, D. \& J.A. Vargas. 1984. Diversity of soft-bottom benthos in a tropical estuary: Gulf of Nicoya, Costa Rica. Mar. Biol. 81: 97-106.

McIntyre, A.D. 1970. The range of biomass in intertidal sand, with special reference to the bivalve Tellina tenuis. J. Mar. Biol. Ass. U.K. 50: 561-575.

Palacios, J.A., R.A. Cruz, J. Bolaños \& J.A. Rodríguez. 1986. Estudio sobre la biología de Protothaca asperrima (Pelecypoda:Veneridae) III. Ciclo reproductivo. Brenesia 25-26: 23-32.

Pereira, A.I. 1990. Ecología de la alimentación de los correlimos (Aves: Scolopacidae) de una playa fangosa del Golfo de Nicoya, Costa Rica. M.Sc. Thesis. Universidad de Costa Rica, San José.

Phillips, P.C. 1983. Diel and monthly variation in abundance, diversity and composition of littoral fish populations in the Gulf of Nicoya, Costa Rica. Rev. Biol Trop. 31: 297-306.

Reise, K. 1985. Tidal flat ecology. An experimental approach to species interactions. Ecological Studies 54. Springer, Berlin, Germany.

Reise, K. 1991. Macrofauna in mud and sand of tropical and temperate tidal flats, p. 211-216. In M. Elliot \& J.P. Ducrotoy (eds.). Estuaries and coasts. Spatial and temporal intercomparisons. Olsen \& Olsen, Fredensborg, Denmark.

Rodríguez-Sevilla, L., R. Vargas \& J. Cortés. 2009. Benthic, shelled gastropods, p. 333-356. In I.S. Wehrtmann \& J. Cortés (eds.). Marine Biodiversity of Costa Rica, Central America. Monographiae Biologicae 86. Springer, Dordrecht, The Netherlands.

Rojas, J., C.E. Villalobos, F. Chartier \& C.R. Villalobos. 1988. Tamaño, densidad y reproducción de la barba de hacha, Tagelus peruvianus (Bivalvia: Solecurtidae) en el estero de Puntarenas, Costa Rica. Rev. Biol. Trop. 36: 479-483.

Skoglund, C. 1992. Additions to the Panamic Province gastropod (Mollusca) literature 1971 to 1992 . The Festivus XXIV (Suppl.): 1-169.
Szelistowski, W. \& J. Garita. 1989. Mass mortality of sciaenid fishes in the Gulf of Nicoya, Costa Rica. Fish. Bull., U.S. 87: 363-365.

Valdés, A. \& Y.E. Camacho-García. 2004. "Cephalaspidean" heterobranchs (Gastropoda) from the Pacific coast of Costa Rica. Proc. Calif. Acad. Sci. 55: 459-497.

Vargas, J.A. 1987. The benthic community of an intertidal mud flat in the Gulf of Nicoya, Costa Rica. Description of the community. Rev. Biol. Trop. 35: 229-316.

Vargas, J.A. 1988. Community structure of macrobenthos and the results of macropredator exclusion on a tropical mud flat. Rev. Biol. Trop. 36: 287-308.

Vargas, J.A. 1989. A three year survey of the macrofauna of an intertidal mud flat in the Gulf of Nicoya, Costa Rica, p. 1905-1919. In O. Magoon, M. Converse, D. Miner, L.T. Tobin \& D. Clark (eds.). Proc. 6th Symp. on Coastal and Ocean Management, Vol. 2. Amer. Soc. Civil Eng. New York. USA.

Vargas, J.A. 1996. Ecological dynamics of a tropical intertidal mudflat community, p. 355-371. In K.F. Nordstrom \& C.T. Roman (eds.). Estuarine shores: evolution, environments and human alterations. John Wiley \& Sons, London, England.

Vargas, J.A. \& A. Mata. 2004. Where the dry forest feeds the sea: The Gulf of Nicoya estuary, p. 126-135. In G.W. Frankie, A. Mata \& S.B. Vinson (eds). Biodiversity conservation in Costa Rica; Learning the lessons in a seasonal dry forest. University of California, Berkeley, USA.

Vargas, J.A. \& S. Solano. 2011. On Mellitella stokesii and Amphipholis geminata (Echinodermata), from an intertidal flat in the upper Gulf of Nicoya estuary, Pacific, Costa Rica. Rev. Biol. Trop. 59: 193-198.

Víquez, R. \& P. Hargraves. 1995. Annual cycle of potentially harmful dinoflagellates in the Golfo de Nicoya, Costa Rica. Bull. Mar. Sci. 57: 467-475.

Voorhis, A., C.E. Epifanio, D. Maurer, A.I. Dittel \& J.A. Vargas. 1983. The estuarine character of the Gulf of Nicoya, an embayment on the Pacific coast of Central America. Hydrobiologia 99: 225-237.

Wear, R.C. \& J.P.A. Gardner. 2001. Biological effects of the toxic algal bloom of February and March 1998 on the benthos of Wellington Harbour, New Zealand. Mar. Ecol. Prog. Ser. 218: 63-76.

Wood, S., 2006. Generalized additive models: an introduction. Chapman \& Hall/CRC, Boca Raton, USA. 